\title{
Occupational Health and Safety, Work Discipline, Leadership Style Affect Employee Performance
}

\author{
Cut Fitri Rostina ${ }^{1 *}$, Devy Muhani², Tresha Sinaga ${ }^{3}$
}

${ }^{123}$ Prima Indonesia University, Medan, Indonesia

\section{A R T I C L E I N F O}

Article history:

Received 18 August 2020

Received in revised form 25 August 2020

Accepted 18 October 2020

Available online 1

November 2020

Keywords:

Occupational Health and

Safety, Discipline,

Leadership Style,

Performance

\section{A B S T R A C T}

Human Resources is one of the most important things in managing an existing system within an organization or company. Therefore, human resources must be managed as well as possible to improve quality in the company. This study aims to analyze the effect of occupational safety and health, work discipline, and leadership style on employee performance. This type of research is a quantitative descriptive study. This research is explanatory, or so-called pure research or main research. The number of samples in this study were 261 people who were determined using simple random sampling technique. The data in this study were collected using an instrument in the form of a questionnaire. Data were analyzed using t-test and f-test. The results showed that in partially the occupational safety and health variables have a significant effect on performance which can be seen from the t-count(-2.876) higher than t-table (1.65), the work discipline variable has a significant effect on performance can be seen from the t-count $(11,177)$ higher than $t$-table (1.65), and the variable leadership style has a significant effect on performance which can be seen from the t-count(3.849) higher than t-table (1.65). The variables of occupational safety and health, discipline, and leadership style simultaneously have a significant effect on employee performance, as seen from Fcount $(84,116)$ higher than $\mathrm{F}$ table $(2.65)$ and a significance probability of 0.000 smaller than 0.05 . So, it can be concluded that occupational safety and health, work discipline, and leadership style simultaneously have a significant influence on employee performance.

Copyright (C) Universitas Pendidikan Ganesha. All rights reserved.

\section{Introduction}

Human Resources is one of the factors that affect the level of success of an organization or company. Therefore, the quality of human resources needs to be considered in order to optimize the achievement of organizational or company goals (Hasibuan, 2014; Robbins, 2018) . Employees have a very big role in achieving company success. Employee performance is an important factor in influencing the success rate of an organization or company. Employee performance is an action taken by an employee in carrying out the task / job assigned by the company (Handoko, 2017; V. Rivai \& Sagala, 2014). Along with increasing competition in the business world, companies need high employee performance. Therefore, companies are required to conduct an analysis of the factors that can affect employee performance (Mangkunegara, 2013; Widayatama et al., 2019).

Several indicators that indicate an increase in employee performance include an increase in the amount of production using the same resources, the same amount of production or an increase with fewer resources, and a much larger amount of production with a relatively large addition of resources (Supriyadi, 2010; Lei et al., 2018). High performance is expected to make a positive and significant contribution to the company's performance and capabilities. This is because the company is a synergy and collaboration of all employees and the performance of all company unit teams (Darmanegara, 2013; Suhardono et al., 2019).

Employee performance is influenced by various factors. In general, can be classified into factors that originate from within the employee and originate from outside the employee. Previous research 
shows that one of the factors that affect employee performance is occupational safety and health (K3) (Putra \& Prasetya, 2018; Wibowo \& Widiyanto, 2019; Widari et al., 2018). Occupational safety and health (K3) is defined as an effort to guarantee the integrity and physical and spiritual perfection of workers in a company, or communities around the company or a certain workplace (Alhamda \& Sriani, 2015; Djatmiko, 2016; Liang et al., 2019).

Apart from occupational safety and health, another factor that can affect employee performance is employee work discipline (Binarsih et al., 2013; Handayani Bachri \& Alim, 2014; Istiqomah \& Suhartini, 2015). Work discipline is defined as the ability of workers / employees to comply with the work rules set by the company. Work discipline also refers to the compliance and willingness of workers to comply with any prevailing norms around it (Engelbrecht et al., 2008; Hasibuan, 2014).

Apart from the two factors above, the previous research found that leadership style can also affect employee performance (Afifah, 2018; Erlangga et al., 2013; Prahasti \& Wahyono, 2019). The leadership style in question is the way the company leader acts and influences its members, in this case the employees to achieve company goals (Cahyadi, 2019).

This study aims to analyze the effect of work safety, work discipline, and leadership style on employee performance at PT Perkebunan Nusantara III (Persero).

\section{Methods}

This research uses descriptive quantitative research. This research is explanatory, or what it is called pure research or main research. Explanatory research is a study that aims to explain the position of the variables under study, as well as the influence between one variable and another (Sugiyono, 2014). The research framework that includes the design of the relationship between variables in this study is presented in Figure 1.

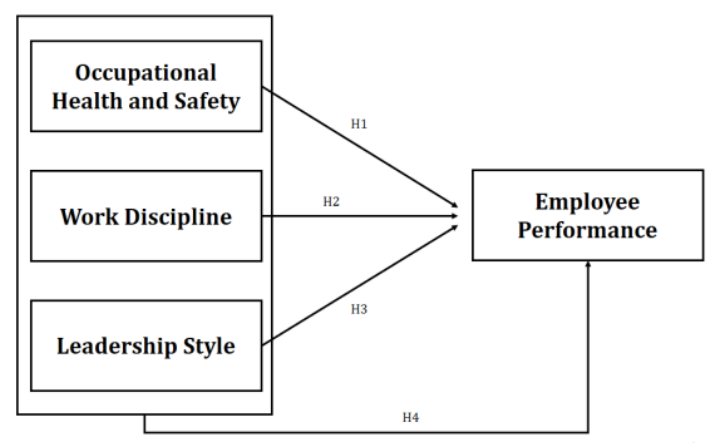

Figure 1. Research framework

The population in this study were employees at PT. Perkebunan Nusantara III (Persero). The sample determination uses simple random sampling technique. This technique is assisted by the help of the Slovin formula with a standard off error rate of 5\%. In this case, sampling is done randomly without considering the equality in the population. Based on the sampling technique, the sample members were 261 people.

Collecting data in this study using an instrument in the form of a questionnaire. A total of 261 respondents participated in filling out this questionnaire. Questionnaires containing questions about occupational safety and health variables, work discipline, and leadership styles, as well as the perceptions they cause on employee performance, are then distributed so that they can be filled in by respondents.

The data size scale used in this study is a Likert scale, namely the range of 1 - 5 scores given, namely the answer SS =Strongly agree (5), S = Agree (4), N = Neutral (3), TS = Disagree (2), STS = Strongly Disagree (1). Data analysis using multiple linear regression analysis techniques. Multiple linear regression analysis technique is used to determine the relationship between the dependent and independent variables simultaneously. Calculation and processing of primary and secondary data uses the help of the SPSS program. 


\section{Results and Discussions}

\section{Results}

Descriptive Analysis Results

The results of the descriptive analysis of the data are presented in Table 1.

Table 1. Descriptive Statistical Analysis Results

\begin{tabular}{lccccc}
\hline Variable & N & Min & Max & Mean & Std. Deviation \\
\hline Occupational Health and Safety (X1) & 261 & 23 & 40 & 34.38 & 2,654 \\
Work Discipline (X2) & 261 & 24 & 40 & 33.37 & 3,006 \\
Leadership Style (X3) & 261 & 26 & 39 & 33.93 & 2,454 \\
Employee Performance (Y) & 261 & 24 & 40 & 33.49 & 3,045 \\
Valid N (listwise) & 261 & & & & \\
\hline
\end{tabular}

\section{Normality Test Results.}

Graph Analysis

Graph analysis of normality test results is presented in Figure 2.

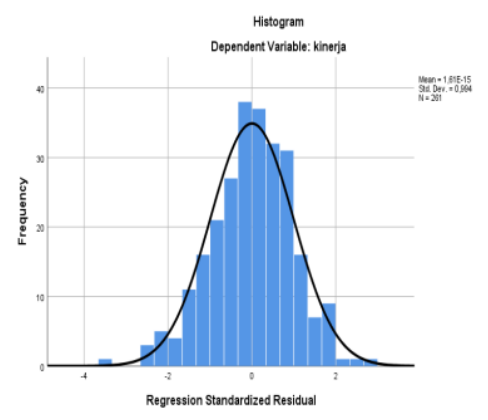

Figure 2. Normality Analysis Graph

From the histogram graph in Figure 1 above, the curve shows the shape of a bell and has an almost equal slope. Based on this, it can be interpreted that the analyzed data is normally distributed.

\section{PP Plot}

The PP Plot Normality Graph is presented in Figure 3.

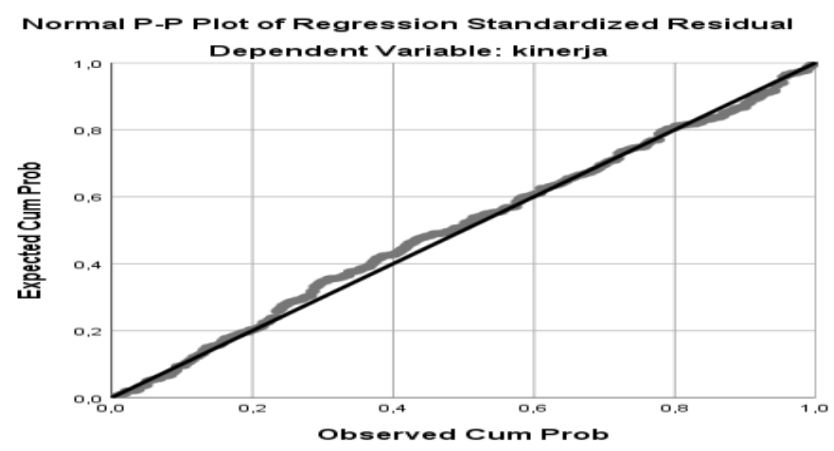

Figure 3. PP Plot Normality Graph

Based on the PP Plot Normality Graph in Figure 2, it can be seen that the data spreads around the diagonal line, the distribution is mostly close to the diagonal line. This means that the data is normally distributed.

The Kolmogorov-Smimov test

The results of the normality test through the Kolmogorov-Smirnov test are presented in Table 2. 
Table 2. The Kolmogorov-Smirnov test

\begin{tabular}{lll}
\hline & Unstandardized Residual & \\
\hline $\mathrm{N}$ & 261 & \\
Normal Parameters & Mean & .0000000 \\
& Std. Deviation & 1.79758425 \\
Most Extreme Differences & Absolute & .051 \\
& Positive & .028 \\
& Negative & -.051 \\
Statistical Test & 1,023 & \\
Asymp. Sig (2-tailed) & .256 & \\
\hline
\end{tabular}

The Kolmogorov-Smimov test shows the results of the normality test using the Kolmogorov Smirnov test show a significant value of $0.256>0.05$. Thus, the Kolmogorov Smirnov test results show that the data is normally distributed.

\section{Multicollinearity Test Results}

The multicollinearity test results are presented in Table 3.

Table 3. Multicollinearity Test Results

\begin{tabular}{ccc}
\hline Variable & Tolerance & VIF \\
\hline Occupational Health and Safety & .947 & 1,056 \\
Work Discipline & .729 & 1,372 \\
Leadership Style & .696 & 1,437 \\
\hline
\end{tabular}

From the table above, VIF $<10$ and tolerance $>0.1$, which indicates that there is no multicollinearity and no problems. It is concluded that this study does not occur multicollinearity or is free from multicollinearity problems.

\section{Heteroscedasticity Test Results} Scatterplot

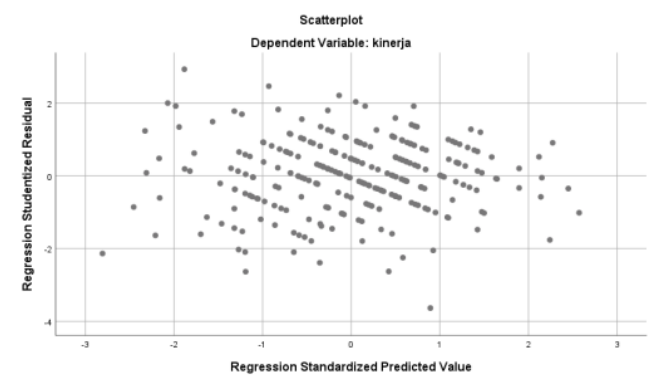

Figure 4. Scatterplot graphics

From the scatterplot graph, it can be seen that the dots spread with an unclear pattern, either above or below the zero (0) on the Y axis, do not converge in one place, so from the scatterplot graph it can be concluded that there is no heteroscedasticity in the regression model. The presence or absence of heteroscedasticity can be seen from the probability of significance, if the significance value is above the $5 \%$ confidence level, it can be concluded that it does not contain heteroscedasticity.

\section{Gletser test}

The results of the heteroscedasticity test are presented in Table 4 .

Table 4. Heteroscedasticity Test Results

\begin{tabular}{lcccccc}
\hline \multirow{2}{*}{ Variable } & \multicolumn{2}{c}{ Unstandardized Coefficients } & \multicolumn{2}{c}{ Standardized Coefficients } \\
\cline { 2 - 6 } & B & Std. Error & B & T & Sig \\
\hline Occupational & Health &, 013 &, 033 &, 025 &, 403 &, 688
\end{tabular}




\begin{tabular}{lccccc}
\hline \multirow{2}{*}{ Variable } & \multicolumn{2}{c}{ Unstandardized Coefficients } & \multicolumn{3}{c}{ Standardized Coefficients } \\
\cline { 2 - 6 } & B & Std. Error & B & T & Sig \\
\hline and Safety & & & & & \\
Work Discipline &,- 009 &, 030 &,- 021 &,- 302 &, 763 \\
Leadership Style &,- 119 &, 036 &,- 241 & $-3,325$ &, 587 \\
Constant & 5,337 & 1,446 & & 3,690 &, 000 \\
\hline
\end{tabular}

Based on Table 4, it can be concluded that the data are normally distributed and do not experience heteroscedasticity problems. This can be seen from the value of Sig> 0.05 , so it can be said that this study is free from heteroscedasticity problems.

\section{Multiple Linear Regression Test Results}

The results of multiple linear regression tests can be seen in Table 5 .

Table 5. Multiple Linear Regression Test Results

\begin{tabular}{lcc}
\hline \multirow{2}{*}{ Variable } & \multicolumn{2}{c}{ Unstandardized Coefficients } \\
\cline { 2 - 3 } & B & Std. Error \\
\hline Constant & 13,258 & 2,380 \\
Occupational Health and Safety &,- 158 &, 055 \\
Work Discipline &, 552 &, 049 \\
Leadership Style &, 226 &, 059 \\
\hline
\end{tabular}

Based on Table 5, in the unstandardized coefficients, the multiple linear regression equation is obtained as follows.

$$
\begin{aligned}
& \mathrm{Y}=13.258-0.158 \mathrm{X} 1+0.552 \mathrm{X} 2+0.226 \mathrm{X} 3+\mathrm{e} \\
& \text { Information: } \\
& \mathrm{Y}: \text { Employee Performance } \\
& \mathrm{X}_{1} \quad \text { : Occupational Health and Safety } \\
& \mathrm{X}_{2} \quad \text { : Work Discipline } \\
& \mathrm{X}_{3} \quad \text { : Leadership Style } \\
& \mathrm{e}: \quad \text { Term of error or error clearance rate }
\end{aligned}
$$

\begin{tabular}{|c|c|c|c|c|c|}
\hline \multirow{2}{*}{ Variable } & \multicolumn{2}{|c|}{ Unstandardized Coefficients } & \multicolumn{3}{|c|}{ Standardized Coefficients } \\
\hline & B & Std. Error & B & $\mathbf{T}$ & Sig \\
\hline Constant & 13,258 & 2,380 & & 5,571 & 000 \\
\hline $\begin{array}{l}\text { Occupational Health } \\
\text { and Safety }\end{array}$ &,- 158 & 055 &,- 131 & $-2,876$ & , 004 \\
\hline Work Discipline &, 552 & 049 &, 580 & 11,177 &, 000 \\
\hline Leadership Style & $226 \mathrm{t}$ & , 059 &, 204 & $\begin{array}{l}3,849 \\
1,652\end{array}$ &, 000 \\
\hline
\end{tabular}

\section{Hypothesis Test Results}

The t-test functions to show how much influence one variable has individually or independently in explaining the variation in the dependent variable. The t-test results can be seen in Table 6 .

Table 6. T-test results

\section{Effect of Occupational Safety and Health on Employee Performance}

Based on Table 6, it is known that Sig. Price $0.004<0.05$ and tcount $<$ ttable $(-2.876<1.652)$ so it can be concluded that occupational health and safety does not have a significant effect on employee performance at PT. Perkebunan Nusantara III (Persero).

\section{The Effect of Work Discipline on Employee Performance}

Based on Table 6, it is known that Sig. Price $0.000<0.05$ and tcount $>$ ttable $(11.177>1.652)$ so it can be concluded that Work discipline has a significant effect on employee performance at PT. Perkebunan Nusantara III (Persero). 


\section{The Effect of Leadership Style on Employee Performance}

Based on Table 6, it is known that Sig. Price $0,000<0.05$ and tcount $>$ ttable $(3,849>1,652)$ so it can be concluded that leadership style has a significant influence on employee performance at PT. Perkebunan Nusantara III (Persero).

Furthermore, the f-test is useful for knowing simultaneously the independent variable has a significant or no effect on the dependent variable. The f-test results are presented in Table 7.

Table 7. Test Results-f

\begin{tabular}{lccccc}
\hline Model & $\begin{array}{c}\text { Sum of } \\
\text { Squares }\end{array}$ & Df & Mean Square & F & Sig. \\
\hline Regression & 888,468 & 3 & 296,156 & 84,116 &, 000 \\
Residual & 904,850 & 257 & 3,521 & & \\
Total & 1793,318 & 260 & & & \\
\hline
\end{tabular}

Based on Table 7, the test results obtained Fcount 84,116 with a significance level of 0,000 . While the Ftable with a confidence level of $95 \%(\alpha=0.05)$ is 2.65. Therefore, Fcount> Ftable (84.116>2.65) with a significant $0.000<0.05$, then $\mathrm{Ha}$ is accepted and $\mathrm{H} 0$ is rejected. This proves that occupational safety and health, work discipline, and leadership style have a significant and simultaneous influence on employee performance at PT. Perkebunan Nusantara III (Persero).

\section{Determination Coefficient Test}

The result of the coefficient of determination test obtained an Adjusted R Square value of 0.490, this means that $49 \%$ of the variation in the dependent variable, namely the performance which can be explained by the variation of the independent variables, is free occupational safety and health, work discipline, leadership style, while the rest is 51\% (100\% - 49\%). And the remaining $51 \%$ varied by other factors not examined in this study such as incentives and employee job satisfaction.

\section{DISCUSSION}

\section{The Effect of Occupational Safety and Health on Employee Performance}

Based on the findings and data analysis that has been done, work safety has a negative and significant effect on employee performance. This is different from the findings of research conducted by (Frans, 2015; Jayaputra \& Sriathi, 2020) which suggests that occupational safety and health has a positive and significant effect on employee performance. The same thing was stated by (Hamzah \& Oktarina, 2015; Hidayat \& Wahyuni, 2016; Widayatama et al., 2019), which suggests that occupational safety and health have a positive contribution in improving employee performance. In this case, occupational safety and health has an influence on the quality of work because with the guarantee of the safety and health of employees, it will provide a sense of security and comfort for employees at work, so that it can improve employee performance.

\section{The Effect of Work Discipline on Employee Performance}

Based on the research findings and data analysis, it was found that work discipline has a positive and significant effect on employee performance. These findings are in line with the results of research conducted by (Handayani Bachri \& Alim, 2014) which states that work discipline has a positive and significant effect on employee performance. The same thing was also found by (Buntarti \& Shrimp, 2015) which suggests that work discipline provides a positive and significant contribution to improving employee performance in a company. In this case, work discipline affects employee performance because when employees work in accordance with the rules and mechanisms that have been regulated and established by the company, it will have a positive impact on employee work efficiency, so that it can improve employee performance. The higher the employee's work discipline, the greater the employee's performance improvement.

\section{The Effect of Leadership Style on Employee Performance}

Based on the results of research and data analysis, it was found that the leadership style provides a positive and significant influence on employee performance. The results of this study are in line with research conducted by (Apandi, 2018) which suggests that leadership style has a positive and significant influence on employee performance. Leadership style is a set of characteristics that company leaders use to influence employee performance (Hasibuan, 2014; Z. Rivai, 2014). In this case, the leadership style has an influence on employee performance because when company leaders apply a participatory and 
persuasive leadership style, it will create harmonious cooperation, foster loyalty and employee participation. So that it can provide motivation for employees to improve their performance.

\section{The Influence of Occupational Safety and Health, Work Discipline, and Leadership Style on Employee Performance}

Based on the results of data analysis that have been carried out show that the variables of occupational safety and health, work discipline, and leadership style simultaneously have a significant influence on employee performance. This finding is in line with the statement (Apandi, 2018; Hafid, 2018; Widari et al., 2018) that occupational safety and health, work discipline, and leadership style are factors that can significantly influence employee performance in the company. This can be due to the fact that at work, employees need a sense of security and comfort in order to work optimally (Liang et al., 2019). In addition, optimal performance is also obtained by obeying the rules or norms set by the company, for example coming and going from work according to the time set by the company.

\section{Conclusion}

Based on the results and discussion that research can be collected, namely the results of the hypothesis partially occupational safety and health have a negative and significant effect on employee performance, the results of the hypothesis partially work discipline have a positive and significant effect on employee performance. The results of the hypothesis that partially the leadership style has a positive and significant effect on employee performance. Based on the results of the analysis and the conclusions of suggestions for the company. Considering the factors of leadership style, safety, and work discipline, both simultaneously and partially, have been proven to have a significant effect on employee performance, therefore the company needs to pay attention to these factors so that employee performance is maintained. It is expected that in providing work safety to employees it should be done with the principle of appropriateness so that the quality desired by the company will be in accordance with what employees want. If this can be done well, it will undoubtedly improve employee performance

\section{References}

Afifah, N. (2018). Transformational Leadership Style, Market Orientation, and Service Quality Towards PDAM Tirta Khatulistiwa Pontianak, West Kalimantan. Equity: Journal of Economics and Finance, 1 (1), 1-23. https://doi.org/10.24034/j25485024.y2017.v1.i1.2053

Alhamda, S., \& Sriani, Y. (2015). Textbook of Public Health Sciences (IKM). Deepublish.

Apandi. (2018). The Influence of Leadership Style and Motivation on Employee Performance at the Bureau of General Affairs and Finance, University of Lampung. Scholar: Journal of Education and Learning, 12 (1), 61-74. https://doi.org/10.30957/cendekia.v12i1.463

Binarsih, SR, Istiatin, \& Setyawati, W. (2013). The influence of leadership, work discipline and communication on the work motivation of the employees of the Surakarta civil service agency. Sharia Business Management, 6 (1), 1205-1220.

Buntarti, RS, \& Udjang, R. (2015). Compensation and Work Discipline on Employee Performance with Length of Work as Control Variables. JPSB, 3 (2). https://doi.org/10.26486/jpsb.v3i2.458

Cahyadi, B. (2019). The Effect of Leadership Style and Work Environment on Employee Performance in an Islamic Perspective (PT Asyki Case Study). Amwaluna: Journal of Islamic Economics and Finance, 3 (1). https://doi.org/10.29313 /amwaluna.v3i1.4141

Darmanegara, I. (2013). Effect of Spiritual Intelligence and Asta Brata Leadership The Culture of Tri Hita Karana and Employment Performance. IOSR Journal of Business and Management (IOSR-JBM), (2), $05-12$.

https://www.academia.edu/28833912/Effect_of_Spiritual_Intelligence_and_Asta_Brata_Leadership _to_the_Culture_of_Tri_Hita_Karana_and_Employment_Performan.

Djatmiko, RD (2016). Occupational Health and Safety. Deepublish.

Engelbrecht, AS, Johanita., S., \& Louis, VDB (2008). Perceived fairness of disciplinary procedures in the public service sector: an exploratory study. SA Journal of Human Resource Management, 6 (2), 1-8. https://hdl.handle.net/10520/EJC95874 
Erlangga, F., Frinaldi, A., \& Magriasti, L. (2013). The Influence of Paternalistic Leadership Style on Work Motivation of Social Service Employees and Manpower in Padang City. Journal of the Humanus, 12 (2), 174-195. https://doi.org/10.24036/jh.v12i2.4037

Frans, A. (2015). The Effect of Occupational Health and Safety (K3), and Incentives on Motivation and Employee Performance in the Production Section. Journal of Society, Culture, and Politics, 28 (4), 219-226. https://doi.org/10.20473/mkp.V28I42015.219-226

Hafid, H. (2018). The Effect of Competence, Leadership and Work Discipline on Employee Perform ance at Samsat Polewali Mandar. DeReMa Journal of Management, 13 (2), 286-310. https://doi.org/10.19166/derema.v13i2.1004

Hamzah, A., \& Oktarina, N. (2015). The Influence of Implementation of Occupational Safety and Health, Office Facilities and Work Experience on Employee Performance of the Central Java rovince Health Office. Economic Education Analysis Journal, 4 (1), 111-121. http://journal.unnes.ac.id/sju/index.php/eeaj/article/view/4687

Handayani Bachri, \& Alim, A. (2014). The Influence of Work Motivation and Discipline on Employee Performance at the Martapura Religious Court. Journal of Management Insights, 2 (3), 289-299. http://dx.doi.org/10.20527/jwm.v2i3.20

Handoko, TH (2017). Manajemen. BPFE.

Hasibuan, MS (2014). Manajemen Sumber Daya Manusia. Bumi Aksara.

Hidayat, N., \& Wahyuni, I. (2016). Occupational Safety and Health Studies in Workshop in the Department of Civil Engineering Education and Planning, Faculty of Engineering, YSU Journal of Technology and Vocational Education, 23 (1), 51-66. https://doi.org/10.21831/jptk.v23i1.9355

Istiqomah, SN, \& Suhartini. (2015). The Influence of Work Discipline and Communication Climate on mployee Performance of Yogyakarta City Transportation Service, with Work Motivation as an Intervening Variable. Journal of Business Strategy, 19 (1), 89-97. https://doi.org/10.20885/jsb.vol19.iss1.art8

Jayaputra, KH, \& Sriathi, AAA (2020). The Effect of Occupational Health and Safety (K3) Programs, Work Environment, and Organizational Commitment on Employee Performance. Management EJournal, 9 (7), 2642-2662. https://doi.org/10.24843/EJMUNUD.2020.v09.i07.p09

Lei, Z., Tang, W., Duffield, C.F., Zhang, L., Hui, F.K.P., You, R. (2018). Qualitative Analysis of the Occupational Health and Safety Performance of Chinese International Construction Projects. Sustainability, 10(12). https://doi.org/10.3390/su10124344

Liang, K., Fung, I.W.H., Xiong, C., Luo, H. (2019). Understanding the Factors and the Corresponding Interactions That Influence Construction Worker Safety Performance from a Competency-ModelBased Perspective: Evidence from Scaffolders in China. International Journal of Environmental Research and Public Health, 16(11). https://doi.org/10.3390/ijerph16111885

Mangkunegara. (2013). Human Resource Management for Companies (1st ed.). PT. Remaja Rosdakarya.

Prahasti, S., \& Wahyono. (2019). The Influence of Leadership Style, Organizational Culture, and Work Environment on Employee Performance with Job Satisfaction as a Mediator. Economic Education $\begin{array}{lllll}\text { Analysis } & \text { Journal, } & 7 & \text { 543-552. }\end{array}$ https://journal.unnes.ac.id/sju/index.php/eeaj/article/view/28257

Putra, RE, \& Prasetya, A. (2018). The Effect of Occupational Health and Safety Programs on Work Motivation and Employee Performance. Journal of Business Administration (JAB), 56 (2), 153-159. http://administrasibisnis.studentjournal.ub.ac.id/index.php/jab/article/view/2396

Rivai, V., \& Sagala, EJ (2014). Human Resource Management for Companies: From Theory to Practice (3rd ed.). Rajawali Pers.

Rivai, Z. (2014). Leadership and Organizational Behavior. Raja Grafindo Persada.

Robbins, SP (2018). Organizational Behavior (12th ed.). Salemba Empat.

Sugiyono. (2014). Metode Penelitian Kuantitatif, Kualitatif, dan R\&D. Alfabeta. 
Suhardono, S., Noorachmat, B.P., Ismayana, A. (2019). Pemantauan Kinerja Sistem Manajemen Kesehatan Keselamatan Kerja Lindung Lingkungan berdasarkan ISO 45001, 14001 dan 9001 di KSO CESL. Journal of Natural Resources and Environmental Management, 9(3). https://doi.org/10.29244/jpsl.9.3.840-860

Supriyadi. (2010). The effect of work safety on employee performance at CV. Main Sriwijaya in Bandar Lampung. Journal of Science and Innovation, 6 (1), 15-21.

Wibowo, P., \& Widiyanto, G. (2019). The Influence of Occupational Safety and Health and Work Environment on Employee Performance in Production Section at Tom's Silver Company Yogyakarta. Journal of Economics and https://jurnal.ubd.ac.id/index.php/PE/article/view/170

Widari, LA, Zulfhazli, A., \& Rizky, M. (2018). Analysis of the Effect of Occupational Safety and Health (K3) on Construction Worker Performance (Case Study of The Manhattan Mall and Condominium Project). Terrace Journal, 8 (1), 329-338. https://dx.doi.org/10.29103/tj.v8i1.144

Widayatama I., Syah T.Y.R., Anindita R.. (2019). Health and Safety System Implementation of Construction Project Work Into Corporate Culture to Increase Performance. Russian Journal of Agricultural and Socio-Economic Sciences, 89(5), 135-139. https://doi.org/10.18551/rjoas.2019-05.16 